\title{
Some considerations on the application of the FLO-2D model for debris flow hazard assessment
}

\author{
V. D’Agostino ${ }^{1} \&$ P. R. Tecca ${ }^{2}$ \\ ${ }^{I}$ Department of Land and Agroforest Environments, Padova University, \\ Italy \\ ${ }^{2}$ CNR-IRPI, Padova, Italy
}

\begin{abstract}
The two-dimensional flood routing model FLO-2D, with the capabilities of simulating non-Newtonian sediment flows, is becoming more widely used to route debris flows over alluvial fans of alpine torrents and to delineate hazard areas of inundation.

Nevertheless the different applications described in the literature are not comparable, because they are based on different assumptions related to the numerous parameters governing the debris flow simulation. This paper reports the applications of the FLO-2D computer model and discusses the assumptions made for the replication of two well documented debris flow events at Fiames (Belluno) and Rio Dona (Trento) in the Eastern Dolomites.

The simulation results are consistent with the field observations in terms of maximum flow depths and the extent of the inundated areas in the two study sites. These two applications have enhanced the experience for the requirements of model input data in small alpine catchments, in particular the assessment of the main rheological parameters of flows, that are crucial in the design of debris flow countermeasures; leading to a proposed simplification in choosing the FLO-2D rheological parameters; and facilitating the results comparison and their interpretation among different FLO-2D simulations.

Keywords: Alps, debris flow, hazard mapping, 2D model.
\end{abstract}

\section{Introduction}

Laboratory and field researches are available in the literature on the debris flow reology. The main aim of such investigations is the capability to model 
propagation of water-sediment mixtures for a range volumetric concentration $\left(\mathrm{C}_{\mathrm{v}}\right)$ from $10 \%$ to $55-65 \%$. The use of these results is not yet mature, in the sense that the kind of numerical model and the adopted rheogramm affect the choice of viscosity ( $\mu$, Pa s) and critical shear strenght $\left(\tau_{\mathrm{c}}\right)$ (yield stress).

Widespread debris flow models are the depth-averaged models. They assume debris flow as a homogenoeous fluid, whose velocity is well represented by the mean value along the flow depth. Depending on the kind of mixture, several constitutive rheogramms have been proposed to describe debris flow (Ancey [1]):

(i) Lahar-like mixtures behaviour may be described using a Newtonian constitutive law as a first approximation:

$$
\tau=\mu(d u / d y)
$$

being $\tau$ the total shear stress $(\mathrm{Pa})$ and $\mathrm{du} / \mathrm{dy}$ the shear rate $\left(\mathrm{s}^{-1}\right)$ related to a local $\mathrm{u}$ velocity. Viscosity depends on $\mathrm{C}_{\mathrm{v}}$ and is usually very high $\left(10^{3} \mathrm{~Pa} \mathrm{~s}\right)$ (Wan and Wang [2]), and several order of magnitude higher than that of the clear water $\left(1.0 \times 10^{-3}-1.5 \times 10^{-3} \mathrm{~Pa}\right.$ s for temperatures from 20 to $\left.5^{\circ} \mathrm{C}\right)$.

(ii) Muddy debris flows are often represented by means of a Bingham or Herschel-Bulkley model; the last one has the form:

$$
\tau=\tau_{c}+\mathrm{v}(d u / d y)^{n}
$$

where $v$ is the Bingham or Herschel-Bulkley viscosity and $n$ a positive parameter $\left(n=1\right.$ corresponds to the Bingham model). It has been shown that $\tau_{c}$ increases exponentially with $\mathrm{C}_{\mathrm{v}}$ and can be successfully applied to fluxes having a fine friction $(>40 \mu \mathrm{m})$ percentage higher than (10\%) (Coussot and Piau [3]). In the Alps, bulk yield stress values $(\tau)$ range from 500 to $15000 \mathrm{~Pa}$ and the ratio $\tau_{\mathrm{c}} / \mathrm{V}$ falls usually in the field 3-10 (Coussot [4]). Coussot et al. [5] tested different suspensions (maximum diameter $0.4 \mathrm{~mm}$ ) derived from the Moscardo torrent debris flow (Northeastern Italy). Authors used a rheometer equipped with parallel plates and obtained a satisfactory fitting of eq.(2) with $n=0.33$. Interpolation of $v$ and $\tau_{\mathrm{c}}$ values published by Coussot et al. [5] is represented in Figure 1.

Same Authors integrated data of laboratory rheometer, inclined plane test, large scale rheometer and field test and proposed a rheology for the complete material constituting the debris flow: $\mathrm{n}=0.33, \tau_{\mathrm{c}}=2935 \mathrm{~Pa}$ and $\mathrm{v}=2190 \mathrm{~Pa} \mathrm{~s}^{1 / 3}$, giving an example of a low $\tau_{c} / \mathrm{v}$ ratio (1.3) for the whole mixture.

(iii) Granular debris flow behaviour is expected to be frictional and collisional; different models have been proposed for its interpretation (Takahashi [6]) for taking into account the turbolent-dispersive stresses and collisions between corser sediment particles. These mechanisms can induce a magnitude of shear stress not easy to eastimate both in laboratoty, both in the field.

A comprehensive model for debris mixtures have been proposed by O'Brien and Julien [7], by assuming the following constitutive equation (quadratic model): 


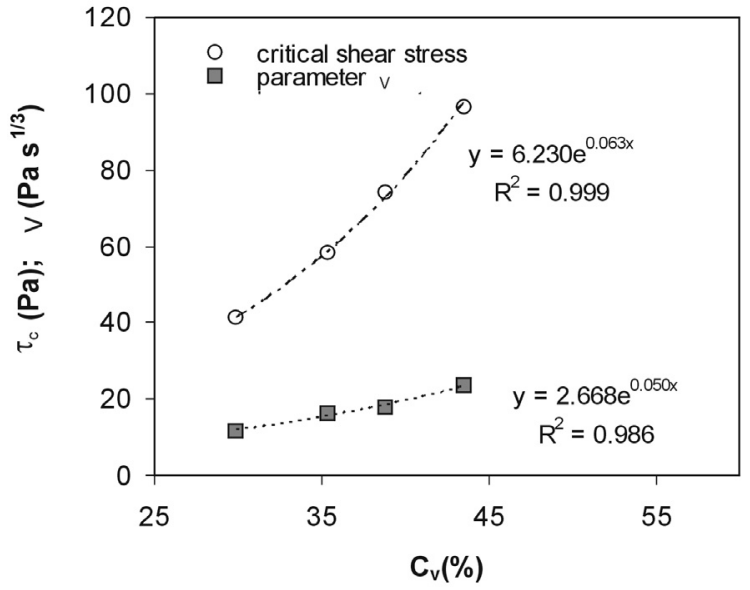

Figure 1: Fitting of experimental data of Coussot et al. [5] for eq. (2) and $\mathrm{n}=0.33$.

$$
\tau=\tau_{c}+\mu(d u / d y)+C(d u / d y)^{2}
$$

where $\mathrm{C}$ is the inertial stress coefficient. Rewriting eq.(3) in terms of depthintegrated dissipative friction slope $\left(\mathrm{S}_{\mathrm{f}}\right)$ it follows (O'Brien et al. [8]):

$$
S_{f}=\frac{\tau_{c}}{\gamma_{m} h}+\frac{K \mu V}{8 \gamma_{m} h^{2}}+\frac{n_{d}^{2} V^{2}}{h^{4 / 3}}
$$

being $\gamma_{\mathrm{m}}$ the specific debris flow weight; $\mathrm{h}$ the flow depth, $\mathrm{V}$ the mean velocity, $\mathrm{K}$ the resistence parameter for laminar flow, $\mathrm{n}_{\mathrm{d}}$ the turbolent dispersive $\mathrm{n}$ of Manning value $\left(\mathrm{n}_{\mathrm{d}}=0.054 \mathrm{n} \mathrm{e} \mathrm{e}^{6.09 \mathrm{Cv}} ;\right.$ FLO2-D [9]). The parameter K equals 24 for smooth wide rectangular channels but increases significantly with roughness. A value of $\mathrm{K}=2285$ is suitable to simulate mud-debris flows (O'Brien [9]). Viscosity and critical shear stress of eq.(4) are supported by laboratory measurements (O'Brien and Julien [10]), correlating these variables to $\mathrm{C}_{\mathrm{v}}$. The equations have the form:

$$
\begin{gathered}
\mu=\alpha_{1} \quad e^{\beta_{1} C_{v}} \\
\tau_{c}=\alpha_{2} e^{\beta_{2} C_{v}}
\end{gathered}
$$

Coefficients $\alpha_{1}, \beta_{1}$, and $\alpha_{2}, \beta_{2}$, were calibrated for different mixtures (O'Brien and Julien [10]) and by different Authors (see references in O'Brien and Julien [10]); the range of variation for viscosity $\mu(\mathrm{Pa} \mathrm{s})$ covers approximately the range: $\left[\alpha_{1}=0.004 ; \beta_{1}=8.3\right]$ (Kang and Zhang [11]) - $\left[\alpha_{1}=0.004 ; \beta_{1}=22.1\right]$; for $\tau_{\mathrm{c}}(\mathrm{Pa})$ the field of variation is: $\left[\alpha_{2}=0.0005 ; \beta_{2}=22.2\right]-\left[\alpha_{2}=0.017 ; \beta_{2}=25.6\right]$ (Fei [12]; in 
O'Brien and Julien [10]) (Fig.2). The other two parameters $\mathrm{K}$ and $\mathrm{n}_{\mathrm{d}}$ are not supported by measurements focused on debris flow motion.

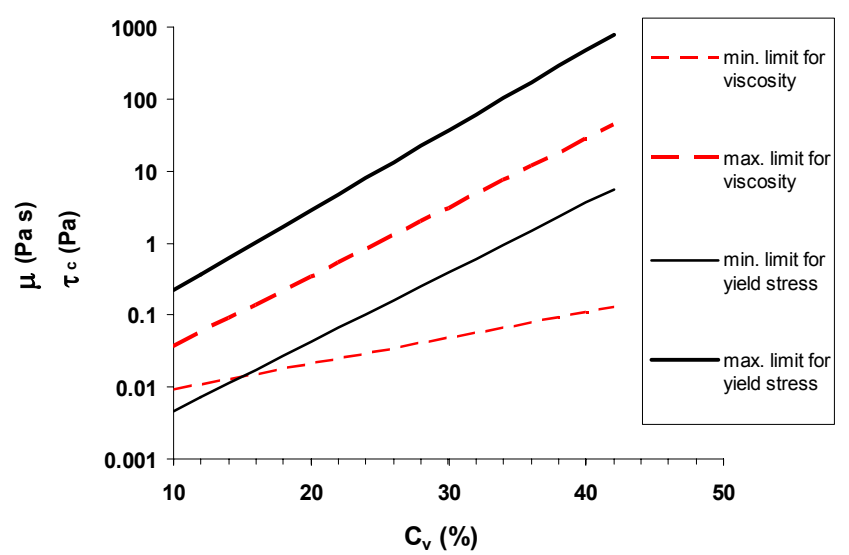

Figure 2: Region of existence for the rheological parameters: viscosity $\mu$, eq. (5), and yield stress $\tau_{\mathrm{c}}$, eq. (6).

Calibration of eq.(4) presents many uncertainties and demands the selection of six rheological or quasi-rheological coefficients $\left(\alpha_{1}, \beta_{1}, \alpha_{2}, \beta_{2} n_{d}, K\right)$. Spite of this, FLO-2D model (O'Brien [9]), where the energy dissipation is founded on eq.(4), gives credit of numerous applications (O'Brien [13], Aleotti and Polloni [14], Bertolo and Wieczorek [15]), for which the simulated floodings (inundated areas, maximum flow depths and velocities) are consisting with the observed ones. In such simulations the combination of the above mentioned coefficients is not always in agreement with their phisics significance, even if they give, on the whole, satisfactory results.

The aim of this paper is to address a suitable calibration of the main rheological parameters of the FLO-2D model through the back analysis of two well documented events in the Dolomites, Fiames and Rio Dona. After calibration, the performance of the FLO-2D code is tested in terms of consistency of the results with the observed data, using different values of $\mathrm{K}$, and empirical coefficients $\alpha_{i}$ e $\beta_{i}$ for the calculation of the viscosity $\mu$ and the yield stress $\tau_{\mathrm{c}}$.

\section{Locations of the study area and description of the events}

Rio Dona and Fiames sites are both located in the Dolomites (North-Eastern Italy).

The two sites have been chosen because for both at least a well documented event exists, with field data on the extent of the flooded area, runout distance, 
volume of the debris flow deposits, flow depths and flow velocity estimated using the superelevation method (Johnson and Rodine [16]).

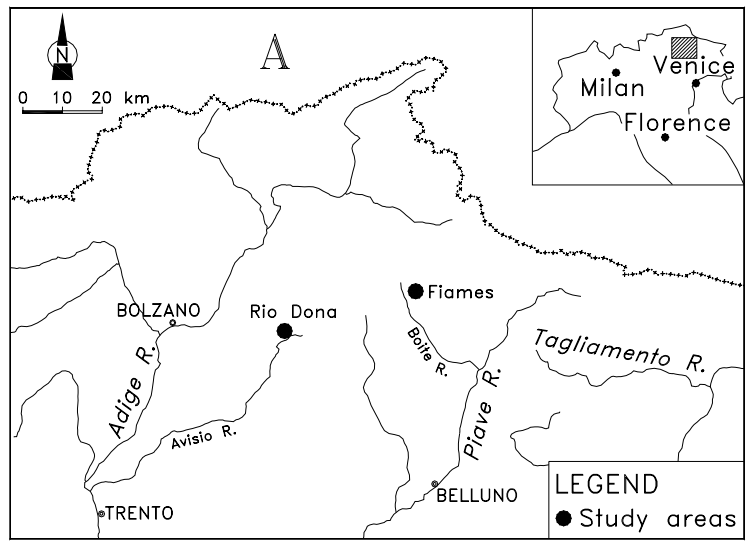

Figure 3: Location of the two debris flow sites.

\subsection{Rio Dona}

Rio Dona catchment, with an area closed to the fan apex of $2.87 \mathrm{~km}^{2}$, and ranging from 1360 to $2064 \mathrm{~m}$ a.s.1, is located on the right side of the Avisio River Valley. The headwaters consist of intrusive, effusive and piroclastic volcanic formations, and carbonates. Middle and lower slopes, formed of marlyarenaceous formations, are covered by talus, including scree, alluvium, morainic deposits and old debris flow deposits, that is the main debris source for floe events. The channel, with a mean slope of $8.5^{\circ}$, has a total length of $3.85 \mathrm{~km}$ and bankfull widths from $3 \mathrm{~m}$ to $6.5 \mathrm{~m}$; a wide alluvial fan, developed from 1440 to $1360 \mathrm{~m}$ a.s.1, has a mean slope of $7.8^{\circ}$. The debris flow of July 9, 1989, occurred after a severe thunderstorm of about one hour. A small failure, located in the talus at about $1750 \mathrm{~m}$ a.s.1., occurred and liquefied into a viscous debris flow, progressively enriching the flowing mass with debris erosion from channel banks and bed. The debris flow spread a volume of $15000 \mathrm{~m}^{3}$ directly into the settled area on the apex, with maximum deposited depths of $4.5 \mathrm{~m}$ at the fan apex. This channelised debris flow transports gravely-sandy poorly sorted material, ranging in size from silt and clay to big boulders (up to $3-4 \mathrm{~m}$ in diameter); the fines content (silt and clay) is approximately $65 \%$ of the total sediment volume.

\subsection{Fiames}

Fiames is a hill-slope debris flow, located on the left side of the Boite River Valley. The upper rock basin, closed to the onset of the main flow path at 1845 $\mathrm{m}$ a.s.1., has a maximum elevation of $2450 \mathrm{~m}$ a.s.1., with an area of $0.16 \mathrm{~km}^{2}$. It is formed of dolomite and limestone cliffs, that are the source of coarse debris and boulders. A thick talus, consisting of poorly sorted debris containing boulders up to $3-4 \mathrm{~m}$ in diameter and including heterogeneous scree, alluvium and old debris 
flow deposits, covers the slope up to the valley bottom $1265 \mathrm{~m}$ a.s.l. The initiation area of the debris flow is located in the talus deposits between 2178 and $1732 \mathrm{~m}$ a.s.l.; the main channel with a mean slope of $20^{\circ}$, has a length of $1500 \mathrm{~m}$, with depths ranging from $3 \mathrm{~m}$ to $6 \mathrm{~m}$ and widths from $10 \mathrm{~m}$ to $22 \mathrm{~m}$. The debris flow of September 5, 1997 was triggered by an intense long rainstorm. The flow initiated at the onset of the main channel, about $1780 \mathrm{~m}$ a.s.1. from the liquefaction of a small debris failure into a flow with progressive entraining of debris from the channel banks erosion and bed scour. At an elevation of $1480 \mathrm{~m}$, where the slope angle decreases to $20^{\circ}-23^{\circ}$, the main channel branches off in several paths, spreading sediments on the slope and leaving lateral deposits further downslope, where the slope angle decreases to $12^{\circ} \div 14^{\circ}$. The total deposited volume was $25000 \mathrm{~m}^{3}$. About $52 \%$ of the total volume deposited on the slope below $1480 \mathrm{~m}$ a.s.l. with depths of $0.8-1.1 \mathrm{~m}$, whilst the remainder flowed further downslope to the Boite River, damaging some buildings for residential and industrial use. The debris flow transports gravely-sandy poorly sorted material, ranging in size from silt and clay to big boulders (up to 1-2 $\mathrm{m}$ in diameter); the fines content does not exceed 15\%.

\section{Calibration of the models}

The calibration of the models is successfully when it produces simulation results consistent with the observed flow behaviour in terms of extent of the flooded area, runout distance, estimate of the deposited sediment volume and flow depth, as well as when the volume conservation is maintained. The rheological parameters yield stress and viscosity of debris flow are key factors for numerical modelling. Since rheological analyses of materials were not available, as it happens in most modeling problems, the choice of the rheological parameters is based on several simulations to back calculate the best combination of $\mu$ and $\tau_{c}$, with the subsequent adjustment of other input parameters like $K$ and $n$ of Manning. Appropriate values $\alpha_{i}$ and $\beta_{i}$ were selected from O'Brien [9], taking into account the grain size of the two debris flow deposits. Rio Dona parameters have been tried in the range of viscous flows, considering a quite large fines component of debris, whilst Fiames parameters have been selected in the range of flows with low viscosity and medium yield stress, due to its smaller percentage of fines in sediments. The reliable determination of the event hydrographs is another important factor for a good quality of the simulation.

\subsection{Rio Dona debris flow}

A volume of $15000 \mathrm{~m}^{3}$ of debris flow material spread on the alluvial fan. It was documented that the event lasted 1 hour, moving down the channel in subsequent viscous waves. The sediment concentration by volume was assumed linearly increasing and decreasing according to the rising and falling limbs of a triangular shaped hydrograph (fig. 4). The peak concentration resulted of $69 \%$, such that the bulked volume routed down the channel was $30000 \mathrm{~m}^{3}$.

The Manning's n-value was 0.04, both for the floodplain and the channel; the specific weight of the mixture $\gamma_{\mathrm{m}}$ and the resistance parameter for laminar flow 
$\mathrm{K}$, were assumed equals to $26.5 \mathrm{kN} / \mathrm{m}^{3}$ and 24 respectively. The best fit with the field observations was obtained by the $\alpha_{\mathrm{i}}$ and $\beta_{\mathrm{i}}$ values listed in Table 1 .

The selected grid element size was $10 \mathrm{~m}$ which resulted in 2340 elements.

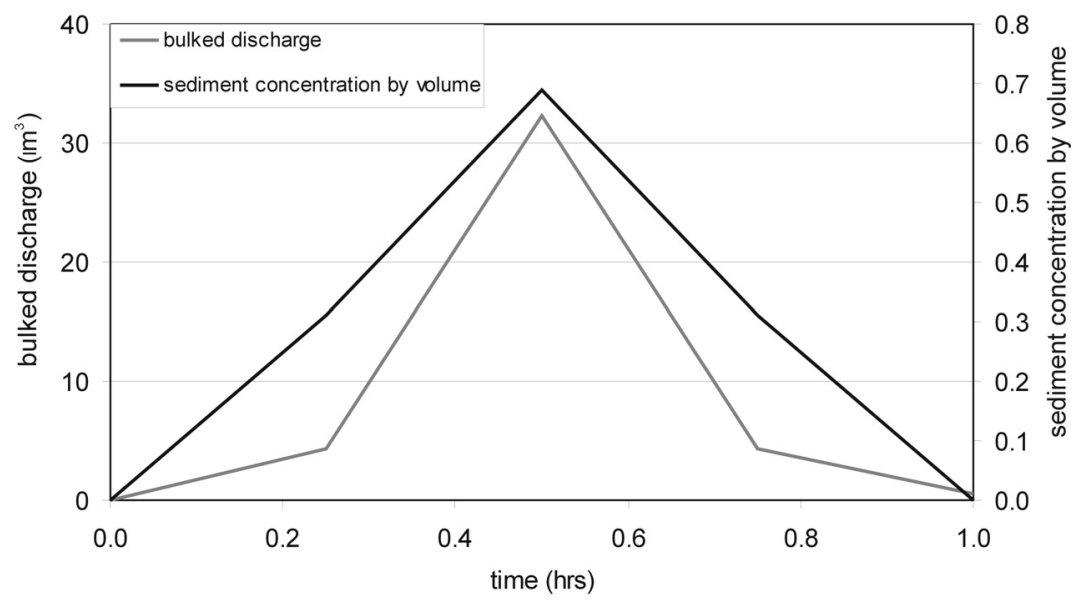

Figure 4: Rio Dona hydrograph.

Table 1: Empirical coefficients and related yield stress and viscosity used for the simulations.

\begin{tabular}{ccccccc}
\hline & $\begin{array}{c}\alpha_{1} \\
\text { (poises) }\end{array}$ & $\beta_{1}$ & $\begin{array}{c}\text { viscosity (Pa s) } \\
\left(\mathrm{C}_{\mathrm{v}}=0.5\right)\end{array}$ & $\alpha_{2}\left(\mathrm{dyn} / \mathrm{cm}^{2}\right)$ & $\beta_{2}$ & $\begin{array}{c}\text { yield stress }(\mathrm{Pa}) \\
\left(\mathrm{C}_{\mathrm{v}}=0.5\right)\end{array}$ \\
\hline Rio Dona & 0.0015 & 22.00 & 9.0 & 0.050 & 22.00 & 299 \\
\hline Fiames & 0.0075 & 14.39 & 1.0 & 0.152 & 18.70 & 175 \\
\hline
\end{tabular}

\subsection{Fiames debris flow}

A total volume of $25000 \mathrm{~m}^{3}$ was released over the slope, from the actual debris flow initiation zone, at an elevation of $1732 \mathrm{~m}$ a.s.l.

The selected grid element size was $5 \mathrm{~m}$ which resulted in 34396 elements. The water hydrograph used to replicate the debris flow of September 5, 1997 has been obtained applying the hydrologic model CLEM (Cazorzi [17]) to the rainfall recorded on the same date in the nearby meteo station of Faloria (BL). A sediment concentration by volume was assigned to the hydrograph, ranging between not less than $30 \%$ along the rising and falling limbs of the hydrograph, and a maximum of $60 \%$ corresponding to the mature debris flow. The water peak discharge was assigned a sediment concentration slightly less than the frontal wave to account for water dilution (fig. 5).

The Manning's n-value was 0.1 , typical for open ground with debris; the specific weight of the mixture $\gamma_{\mathrm{m}}$ and the resistance parameter for laminar flow $\mathrm{K}$, were assumed equals to $26.5 \mathrm{kN} / \mathrm{m}^{3}$ and 2285 respectively. The best fit with the field observations were obtained by the $\alpha_{\mathrm{i}}$ and $\beta_{\mathrm{i}}$ values listed in Table 1 . 


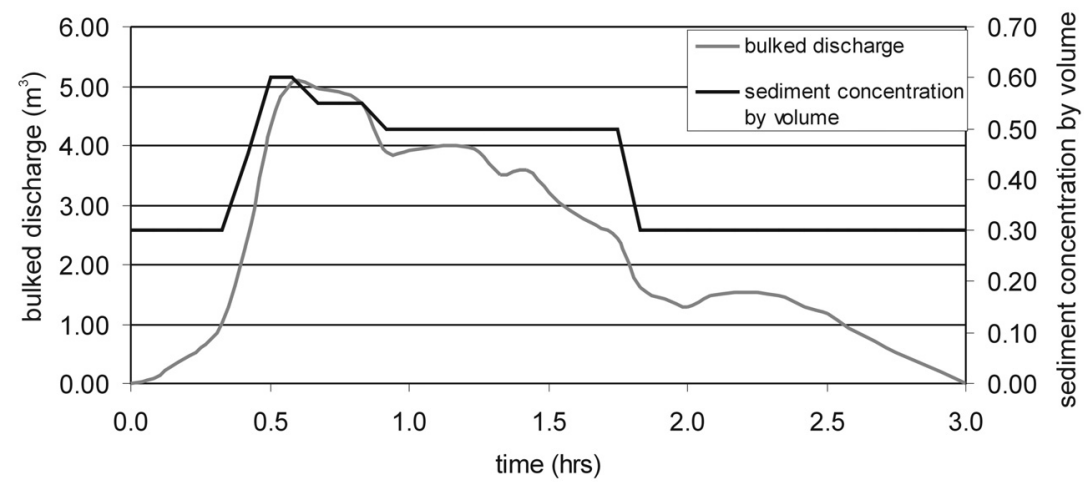

Figure 5: Fiames hydrograph.

\section{Sensitivity analyses}

In order to evaluate the influence of $\mathrm{K}$ and of the rheological parameters on the simulation results, a parametric study has been undertaken. Assuming as initial conditions the calibrated simulations that provided the best fit with field observation, six simulation tests in all were performed for three different values of $\mathrm{K}(24,1000,2285)$ and for the two selected rheological parameter sets, each one applied to both Rio Dona and Fiames (table 1). On both the floodplains we monitored three control points: at the fan apex (A), at the toe of the fan (C), and at an intermediate position (B) between the points A and C. The simulations have been analysed in terms of maximum depths and velocities, flooded area and runout distances. This last parameter was computed for the Dona torrent in relation to the overflow occurred on the left, near the fan apex and for Fiames by considering the propagation from point A to the Boite River.

In a first step, for both basins, we compared the influence of $\mathrm{K}$ variation when the correct rheology is selected. Fig. 6 reports the Dona torrent maximum depth variations in percentage at the three control points (appropriate $\mathrm{K}$ value is 24).

The graph shows an increasing deviation according to $\mathrm{K}$ increasing, with maximum overestimated depth values close to $20-30 \%$ (points A, B) and $40 \%$ (point $\mathrm{C}$ ), when $\mathrm{K}$ is 2285 . The companion analysis for Fiames (calibrated $\mathrm{K}$ value equal to 2285) gives maximum overestimation errors for $\mathrm{K}=24$ of about $3 \%$ and $17 \%$ at points $\mathrm{A}$ and $\mathrm{B}$ respectively.

In the second sensitivity analysis we applied the Fiames rheology to the Dona torrent and vice versa. In such comparison the depth variations do not refer to the correct $\mathrm{K}$ value, but, supposing correct a given $\mathrm{K}$, the influence of assuming a mistaken rheology is evaluated. Fiames simulations (fig. 7) point out how the depth errors are in general larger in comparison to the previous analysis, resulting around $100 \%$ at point $\mathrm{B}(\mathrm{K}=1000$ and 2285$)$, and not lower than $35 \%$ at points $\mathrm{A}$ (overestimation) and $\mathrm{C}$ (underestimation), even for the correct $\mathrm{K}$ (2285). When $\mathrm{K}=24$, it occurs a compensation between the too viscous rheology and the low resistance K parameter (fig. 7). 


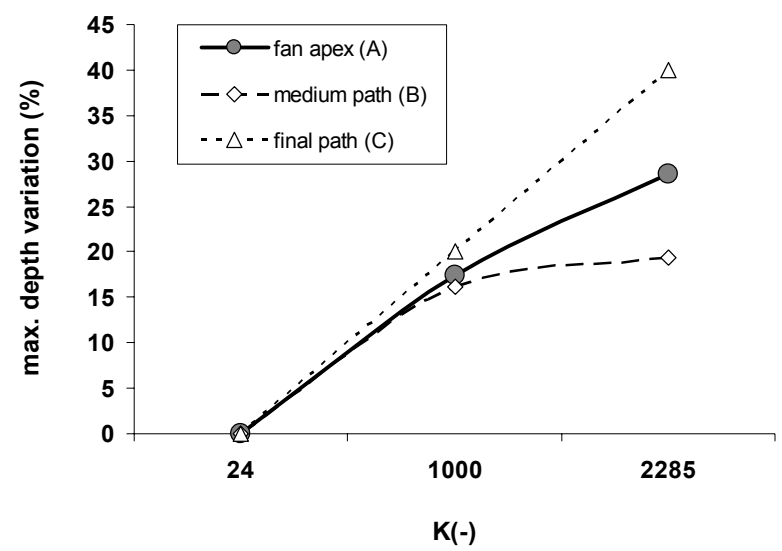

Figure 6: Dona torrent: maximum depths variation with $\mathrm{K}$ (calibrated $\mathrm{K}$ $=24)$.

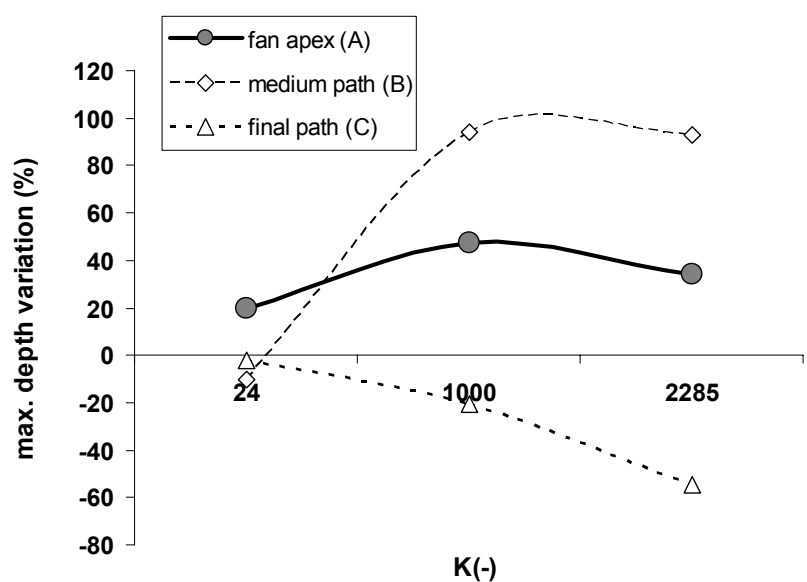

Figure 7: Fiames: maximum depths variation with $\mathrm{K}$ when Dona torrent rheology is applied (calibrated $\mathrm{K}=2285$ ).

In the Dona torrent analysis, the maximum errors (depth underestimation) are equal to $50 \%$ and about $25 \%$ for points $\mathrm{A}$ and $\mathrm{B}$ respectively, independently of $\mathrm{K}$ values. At point $\mathrm{C}$ there is a depth overestimation of $20 \%$ for $\mathrm{K}=24$, and maximum error of $60 \%$ (depth underestimation) for $K=2285$. Also for the Dona torrent the error weight - in terms of maximum depth variation - in assuming a wrong rheology is higher respect to the assumption of a wrong $\mathrm{K}$ and a right rheology (fig. 6). 
The specular analysis in terms of maximum velocity variation gives errors similar to the depth analysis for the Dona torrent; errors are of the same order both for wrong $\mathrm{K}$ or wrong rheology. For Fiames, the error in $\mathrm{K}$ assumption affects, in general, velocity variation (points $\mathrm{A}$ and $\mathrm{B}$ ) more than it occurs when assuming a wrong rheology.

Further remarks descend on the spatial distribution of the flooded area and runout distance. Fig. 8 shows the inundated areas of the Dona torrent, using the appropriate rheology and different $K$. The lowest $K(K=24)$ causes a more fragmentary and braided debris flow propagation. Increasing $K$ values (1000, 2285 ) induce a progressive concentration all around the main propagation route.

Although the inundated areas increase with rising $\mathrm{K}$ values, the evaluation of the calibrated simulation $(\mathrm{K}=24)$, which displays the smaller flooded area, is also important in terms of hazard assessment. In fact, it evidences a zone affected by the flow, at the left side of the channel, close to the fan apex that is neglected by the others K simulations. Runout distance at the left side of the fan apex (fig. 8), reduces along with $\mathrm{K}$ values, up to $40 \%$ for $\mathrm{K}=2285$.
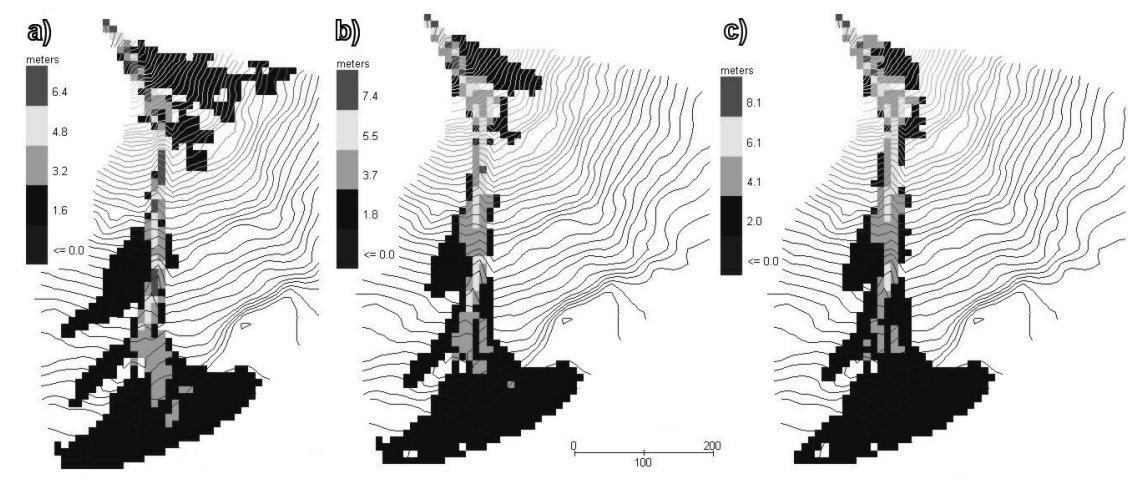

Figure 8: Dona torrent. Maps of maximum flow depths (appropriate rheology): calibrated simulation $\mathrm{K}=24$ (a), simulations $\mathrm{K}=1000$ (b) and $\mathrm{K}=2285$ (c).

When the appropriate rheology is applied to Fiames, simulation for $\mathrm{K}=1000$ and $K=2285$ give similar distribution of the flooded area. When a $K=24$ is applied, the simulation produces braided flow propagation in comparison to the $\mathrm{K}=2285$ simulation (fig. 9). Results show a stronger influence of $\mathrm{K}$ parameter on the extent of the inundated area, whilst the runout distance appears to be under the principal influence of the rheology. In fact, with the most reliable viscosity and yield stress parameters, the flow always reaches the Boite River valley.

\section{Final remarks}

Debris flow modeling can be an important tool for hazard assessment as long as reliable input data required by the code (DEM, hydrological data and rheological 
parameters), are available. Results of modeling of two debris flows in the Dolomites, using FLO-2D, increase experience for the requirements of model input for debris flow simulation. The parametric analysis revealed that mostly rheological parameters and $\mathrm{K}$ values influence final deposits distribution, runout and thickness, and outlines the following main points:

(1) As rheological investigations are not so common, a reliable calibration of the model must be undertaken on the basis of well documented debris flow events; field data should include, at least, extent of flooded area, runout distance and deposits depth.

(2) The selection of trial rheological parameters should address in a range of viscosity and yield stress values that take into account the grain size of debris flow material, as it brings out the viscous character of the flow.

(3) For both Dona torrent and Fiames, it is evident that error in assuming a wrong rheology weights, in terms of maximum depth, more than if a wrong $\mathrm{K}$ is assumed. Rheology and $\mathrm{K}$ have the same influence on velocity estimates for Dona torrent; for Fiames simulation, K has, on velocity values, an influence stronger than rheology.

(4) $\mathrm{K}$ controls in both debris flows the extent of flooded area: the higher is $\mathrm{K}$, the larger is the deposition area. Runout of the main flow path depends mainly from rheology, and this is evident in particular for Fiames.

(5) The most convenient way to lead a simulation is to start from a medium value of K (1000) and then back calculate the rheological parameters that produce the best fit with field observations.

(6) When a good consistency with field data has been reached, velocities can be adjusted, varying the $\mathrm{K}$ parameter.
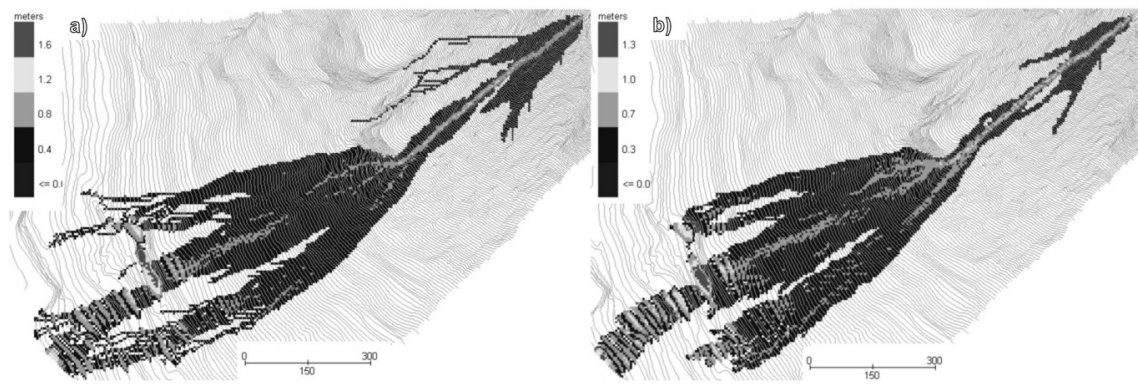

Figure 9: Fiames. Maps of maximum flow depths (appropriate rheology): simulation $\mathrm{K}=24$ (a), and calibrated simulation $\mathrm{K}=2285$ (b).

\section{References}

[1] Ancey C., Debris flows and related phenomena. Geomorphological Fluid Mechanics, eds. N.J. Balmforth \& A. Provenzale, Springer-Verlag: Heidelberg, pp. 528-547, 2001. 
[2] Wan Z. \& Wang Z., Hyperconcentrated flow. IAHR Monograph, Balkema: The Netherlands, 1994.

[3] Coussot P. \& Piau J.M., A large scale field coaxial cylinder rheometer for the study of the rheology of natural coarse suspensions. Journal of Rheology, 39(1), pp. 105-124, 1995.

[4] Coussot P., Les laves torrentielles. Connaissances à l'usage du praticien. Cemagref Editions: Grenoble, France, pp. 1-179, 1996.

[5] Coussot P., Laigle D., Arattano M., Deganutti A.M. \& Marchi L., Direct determination of rheological characteristics of debris flow. Journal of Hydraulic Engineering, 124(8), pp. 865-868, 1998.

[6] Takahashi T., Debris flow. Balkema: Rotterdam, The Netherlands, pp. 1$165,1991$.

[7] O'Brien J.S. and Julien P.Y., Physical properties and mechanics of hyperconcentrated sediment flows. Proc. ASCE Spec. Conf. on Delineation of Landslides, Flash Floods and Debris Flow Hazards in Utah, University of Utah at Logan, Utah, pp. 260-279, 1985.

[8] O’Brien J.S., Julien P.Y., Fullerton W.T., Two-dimensional water flood and mudflow simulation. Journal of Hydraulic Engineering, ASCE, 119(2), pp. 244-259, 1993.

[9] FLO-2D, 2-Dimensional Flood Routine Model Manual. Version 2004.10. FLO-2D Software Inc., Nutrioso, AZ 85932, 2004.

[10] O'Brien J.S. and Julien P.Y., Laboratory analysis of mudflows properties. Journal of Hydraulic Engineering, ASCE, 114(8), pp. 877-887, 1988.

[11] Kang Z. and Zhang S., A preliminary analysis of the characteristics of debris flow. Proc. Int. Symposium on River Sedimentation, Beijing, China, pp. 260-279, 1980.

[12] Fei X. J., Bingham yield stress of sediment water mixtures with hyperconcentration. Journal of Sediment Resources, Beijing, China, pp. 19-28, 1981.

[13] O’Brien J.S., Reasonable assumptions in routing a dam break mudflow. Third International Conference on Debris-flow Hazards Mitigation: Mechanics, Prediction and Assessment, Davos, Switzerland, eds. D. Rickenmann \& C. Chen, Millpress: Rotterdam, pp. 683-693, 2003.

[14] Aleotti P. \& Polloni G., Two-dimensional model of the 1898 Sarno debris flows (Italy): preliminary results. Third International Conference on Debris-flow Hazards Mitigation: Mechanics, Prediction and Assessment, Davos, Switzerland, eds. D. Rickenmann \& C. Chen, Millpress: Rotterdam, pp. 553-563, 2003.

[15] Bertolo P. \& Wieczorek G.F., Calibration of numerical models for small debris flows in Yosemite Valley, California, USA. Natural Hazards and Earth System Sciences, EGU, 5, pp. 993-1001, 2005.

[16] Johnson A.M. \& Rodine J.R., Debris flow (Chapter 8). Slope Instability, eds. D. Brunsden \& D.B. Prior, Wiley: Chichester, pp. 257-361, 1984.

[17] Cazorzi F., HyGrid2k2, Guida di riferimento. Università degli Studi di Udine, 2002. 